PTK, Vol.2 No.1 2021

ISSN: 2747-1977 (Print) / 2747-1969 (Online)

DOI: https://doi.org/10.53624/ptk.v2i1.54

\title{
Pengembangan Media Pembelajaran Tematik Cutter (Cube Letter) Untuk Kelas 1 Sekolah Dasar
}

\author{
Diterima: \\ 5 Januari 2021 \\ Revisi: \\ 25 Januari 2021 \\ Terbit: \\ 1 Februari 2021
}

\author{
Dwi Endah Yulianing Tias \\ SDN Pondokjoyo 01 Kabupaten Jember \\ Kabupaten Jember, Indonesia \\ E-mail:dwiendahy12@gmail.com
}

\begin{abstract}
Abstrak - Penelitian pengembangan ini bertujuan untuk mengembangkan dan menerapkan penggunaan media pembelajaran tematik di kelas 1 SDN Pondokjoyo 01. Metode penelitian yang digunakan di dalam pengembangan media pembelajaran ini adalah metode penelitian dan pengembangan atau Research and Development ( $\mathrm{R} \& \mathrm{D})$. Langkah-langkah penelitian dan pengembangan meliputi: potensi dan masalah, pengumpulan data, desain produk, validasi desain, revisi desain, uji coba produk, revisi produk, uji coba pemakaian, revisi produk tahap akhir, dan produksi massal. Uji efektivitas dan kelayakan media pembelajaran diawali dengan validasi dan revisi desain oleh ahli media, ahli materi, dan guru kelas 1 SD. Selanjutnya, dilakukan uji coba produk terhadap peserta didik dengan skala kecil dan skala besar. Hasil penelitian pada tahap validasi ahli terhadap media pembelajaran menunjukkan bahwa desain media pembelajaran tematik Cutter (Cube Letter) menunjukkan persentase $92 \%$ dengan kriteria sangat layak. Hasil dari ahli materi menunjukkan sangat layak dengan persentase $94 \%$ sedangkan dari guru kelas 1 SD menunjukkan kriteria sangat layak dengan persentase 100\% (expert). Berdasarkan hasil keseluruhan dapat disimpulkan bahwa media pembelajaran tematik Cutter (Cube Letter) untuk kelas 1 SD ini menarik dan dapat dijadikan sebagai media pembelajaran tematik.
\end{abstract}

Kata Kunci-pengembangan, media pembelajaran, tematik cutter

\begin{abstract}
This development research aims to develop and implement the use of thematic learning media in grade 1 elementary school. The research method used in the development of this learning media is the Research and Development $(R \& D)$ method. The research and development steps include: potentials and problems, data collection, product design, design validation, design revision, product testing, product revision, usage testing, final product revision, and mass production. The test of the effectiveness and feasibility of this learning media begins with validation and design revision by media experts, material experts, and 1st grade elementary school teachers. Furthermore, product trials were carried out on small-scale and large-scale students. The results of the research at the validation stage of learning media experts showed that the thematic Cutter (Cube Letter) learning media design showed a percentage of $92 \%$ with very feasible criteria. The results from the material experts showed that they were very feasible with a percentage of $94 \%$ while those of the 1st grade elementary school teachers showed very feasible criteria with a percentage of $100 \%$ (expert). Based on the overall results, it can be concluded that the Cutter (Cube Letter) thematic learning media for grade 1 SD is interesting and can be used as a thematic learning media.
\end{abstract}

Keywords - development, learning media, thematic, thematic Cutter 
ISSN: 2747-1977 (Print) / 2747-1969 (Online)

DOI: https://doi.org/10.53624/ptk.v2i1.54

\section{PENDAHULUAN}

Sekolah Dasar (SD) sebagai salah satu lembaga pendidikan dasar memiliki fungsi yang sangat fundamental dalam menyiapkan sumber daya manusia yang berkualitas. Sekolah dasar adalah jenjang awal dalam proses pendidikan sebelum melanjutkan ke jenjang berikutnya. Danim (Akbar 2009) mengemukakan bahwa persoalan utama yang dihadapi dalam pengelolaan SD saat ini terletak pada masalah mutu, akses, dan peluang pengembangan. Salah satu solusi untuk menyelesaikan masalah tersebut adalah dengan melaksanakan pembelajaran bermakna yang berpusat pada anak dan salah satunya dengan melaksanakan pembelajaran tematik di SD.

Pembelajaran tematik merupakan suatu inovasi atau perubahan dalam pendekatan pembelajaran di SD. Pembelajaran tematik dilakukan sebagai terapan dari pembelajaran terpadu. Pembelajaran terpadu itu sendiri adalah sebuah pendekatan dalam pembelajaran yang secara sengaja mengaitkan beberapa aspek baik dalam mata pelajaran maupun antar mata pelajaran sehingga memberikan pengalaman yang bermakna bagi anak (Depdiknas dalam Trianto 2010).

Pembelajaran yang bermakna bagi peserta didik akan tercipta apabila peserta didik terlibat secara aktif di dalam proses pembelajaran. Proses pembelajaran didalam pembelajaran tematik berusaha untuk mengintegrasikan beberapa mata pelajaran sehingga menjadi pembelajaran yang terpadu. Tetapi proses pelaksanaan pemaduan beberapa mata pelajaran tersebut tidaklah mudah untuk dilaksanakan oleh guru, sehingga tidak dapat menghasilkan pembelajaran yang bermakna bagi peserta didik.

Penerapan pembelajaran dengan menggunakan pendekatan tematik memerlukan persiapan yang tinggi dari guru, dalam hal waktu, sumber, bahan ajar, serta perangkat pedukung lainnya. Pembelajaran tematik memerlukan guru yang kreatif, baik dalam menyiapkan kegiatan/pegalamanan belajar bagi peserta didik, juga dalam memilih kompetensi dari berbagai matapelajaran dan mengaturnya agar pembelajaran menjadi lebih bermakna, menarik dan menyenangkan, serta utuh (Hesty 2008).

Pembelajaran yang bermakna dan menyenangkan akan tercipta apabila didalam proses pembelajaran terdapat sarana dan prasarana yang memadai. Salah satu sarana dan prasarana yang penting didalam pembelajaran tematik adalah tersedianya media pembelajaran ketika proses pembelajaran berlangsung. Sesuai dengan pernyataan diatas bahwa media pembelajaran digunakan sebagai alat untuk mengintegrasikan beberapa mata pelajaran tersebut ke dalam sebuah pembelajaran yang terpadu. Contohnya didalam mata pelajaran bahasa indonesia dan matematika. Melalui sebuah media pembelajaran yang berbasis tematik peserta didik kelas $1 \mathrm{SD}$ 
PTK, Vol.2 No.1 2021

ISSN: 2747-1977 (Print) / 2747-1969 (Online)

DOI: https://doi.org/10.53624/ptk.v2i1.54

bisa meningkatkan kemampuan kognitif (berbahasa dan berhitung), afektif, psikomotor, sosioemosional, dan kinestetiknya.

Kalau kita lihat perkembangannya, pada mulanya media pembelajaran hanya dianggap sebagai alat bantu mengajar guru (teaching aids). Alat bantu yang dipakai adalah alat bantu visual, misalnya gambar, model, objek, dan alat-alat lain yang dapat memberikan pengalaman kongkret, motivasi belajar serta mempertinggi daya serap dan retensi belajar peserta didik. Namun sayang, karena terlalu memusatkan perhatian pada alat bantu visual yang dipakai guru kurang memperhatikan aspek disain dari media pembelajaran tersebut (Sadiman dkk. 2011).

Media pembelajaran sebagai sebuah sarana terpenting didalam proses belajar mengajar dapat digunakan sebagai simulasi kreatif (alat bermain) yang sangat menyenangkan bagi peserta didik. Pada dasarnya, aktivitas yang dilakukan anak-anak setiap harinya adalah bermain, baik di dekolah maupun di lingkungan rumah. Aktivitas bermain yang dilakukan di lingkungan sekolah hendaknya menjadi perhatian guru, karena melalui permainan tersebut banyak manfaat yang bisa diperoleh anak terutama jika permainan tersebut mendapat arahan dari guru. Karena bermain merupakan sebuah aktivitas yang membantu anak untuk mencapai perkembangan yang utuh, baik fisik, intelektual, sosial, moral, dan emosional (Jonh dan Utami dalam Yus 2011). Berdasarkan pernyataan diatas dapat dinyatakan bahwa bermain dapat digunakan sebagai salah satu metode pembelajaran. Bermain juga digunakan guru sebagai wahana atau media pembelajaran untuk membentuk pemahaman melalui kegiatan atau bermain dengan menggunakan berbagai media yang tersedia (Resmini 2010).

Salah satu contoh media pembelajaran tematik yang dapat digunakan sebagai alat didalam kegiatan bermain adalah Cutter (Cube Letter). Dengan menggunakan media pembelajaran Cutter kedalam bentuk sebuah permainan, peserta didik akan menjadi lebih tertarik pada pelajaran bahasa indonesia yang selama ini terkenal dengan mata pelajaran yang membosankan dan mata pelajaran matematika yang selama ini juga dikenal dengan mata pelajaran paling sulit dan tidak disukai oleh peserta didik. Media pembelajaran Cutter ini memiliki beberapa manfaat diantaranya dapat meningkatkan perkembangan kognitif khususnya dalam mata pelajaran Bahasa Indonesia dan Matematika, perkembangan emosi, perkembangan sosial, dan perkembangan fisik.

Sesuai dengan hasil analisis kebutuhan dan berdasarkan observasi yang dilakukan di SDN Pondokjoyo 01 pada bulan Januari 2020 mengenai proses pembelajaran tematik (Bahasa Indonesia dan Matematika) diperoleh hasil bahwa: dari segi metode yang digunakan, guru telah menggunakan metode pembelajaran yang bervariasi didalam menjelaskan materi kepada peserta didik. Guru juga menggunakan sistem pembelajaran yang menyenangkan dengan memberikan kesempatan kepada peserta didik untuk belajar dimana saja bukan hanya didalam kelas (Moving 
Class) sehingga proses pembelajaran tematik berlangsung dengan menyenangkan dan mengakibatkan peserta didik aktif dalam mengikuti proses pembelajaran.

Media pembelajaran yang digunakan di sekolah-sekolah tersebut, jenis medianya sudah bervariasi tetapi penggunaannya masih kurang dan bentuknya masih dalam satuan mata pelajaran. Serta belum adanya media pembelajaran tematik (Bahasa Indonesia dan Matematika) yang dapat digunakan sebagai alat didalam sebuah permainan. Hal ini disebabkan karena kurangnya pengetahuan guru didalam menyediakan dan membuat media pembelajaran per satuan mata pelajaran pada umumnya dan media pembelajaran tematik pada khususnya.

Hasil analisis kebutuhan di atas menjelaskan bahwa sangat dibutuhkan sebuah media pembelajaran tematik (Bahasa Indonesia dan Matematika) yang dapat digunakan sebagai alat didalam sebuah permainan. Sehingga peneliti dapat mengembangkan sebuah media pembelajaran tematik (Bahasa Indonesia dan Matematika) Cutter (Cube Letter) untuk kelas 1. Penggunaan media pembelajaran ini didalam pelaksanaan pembelajaran tematik ini sangat cocok karena dapat menciptakan pembelajaran bermakna dan menyenangkan yang berpusat pada anak.

\section{METODE}

\section{A. Metode Penelitian}

Metode penelitian yang digunakan didalam pengembangan media pembelajaran ini adalah metode penelitian dan pengembangan. Penelitian ini menggunakan model pengembangan Borg and Gall. Penelitian ini dilakukan untuk menghasilkan sebuah produk media pembelajaran tematik Cutter untuk kelas 1 Sekolah Dasar (SD). Media pembelajaran yang dibuat disesuaikan dengan kebutuhan dan karakteristik peserta didik kelas 1 SD. Penelitian ini dilakukan di SDN Pondokjoyo 01 yang beralamat di Jalan Rampal Indah No.79 Desa Pondokjoyo Kecamatan Semboro Kabupaten Jember. Waktu penelitian dan pengembangan dilakukan pada bulan Januari sampai dengan Juni 2020.

\section{B. Prosedur Pengembangan}

Prosedur pengembangan menjelaskan langkah-langkah prosedural yang ditempuh oleh peneliti dalam membuat produk. Sesuai dengan model pengembangan yang digunakan, prosedur penelitian pengembangan media pembelajaran yang ditempuh adalah sebagai berikut: (1) Potensi Masalah, (2) Pengumpulan data, (3) Desain Produk, (4) Validasi desain, (5) Perbaikan Desain, (6) uji coba produk, (7) Revisi produk, (8) Uji Coba pemakaian, (9) Revisi produk, dan (10) Produksi masal. 
PTK, Vol.2 No.1 2021

ISSN: 2747-1977 (Print) / 2747-1969 (Online)

DOI: https://doi.org/10.53624/ptk.v2i1.54

\section{Uji Coba Produk}

Uji coba produk ini dilakukan untuk mengumpulkan data yang digunakan sebagai dasar untuk menetapkan kelayakan produk yang dikembangkan peneliti. Menurut Pedoman Penulisan Karya Ilmiah Universitas Negeri Malang (2010) terdapat lima tahapan dalam uji coba produk ini yaitu: 1) menetapkan desain uji coba; 2) menetapkan subyek uji coba; 3) menetapkan jenis data; 4) menetapkan instrument pengumpulan data; serta 5) teknik analisis data. Angket validasi media pembelajaran berisi kisi-kisi mengenai kriteria sebuah media pembelajaran. Adapun kisikisi kualitas dalam penelitian sebuah media pembelajaran menurut Yuananda (2013) terdiri dari: kriteria pendidikan, tampilan media, dan kualitas teknis. Dalam menggunakan angket ini, para validator diminta mencentang angka-angka berderet yang menunjukkan "sangat baik" (angka 5) atau "tidak baik" (angka 1) dengan kriteria yang tertera sebelumnya (Sukmadinata 2007).

\section{Teknik Analisis Data}

Dalam penelitian ini peneliti menggunakan teknik analisis data dengan cara deskriptif kualitatif dan kuantitatif. Teknik analisis data kualitatif ini dilakukan dengan cara deskriptif kualitatif dengan menguraikan kalimat-kalimat, bukan angka-angka atau tabel. Data kuantitatif dalam penelitian media pembelajaran ini diperoleh dari nilai-nilai yang diberikan para validator terhadap produk media pembelajaran Cutter yang telah dibuat. Uji angket validitas ahli pada media pembelajaran tematik Cutter ini dapat dilakukan dengan membandingkan jumlah skor yang diberikan oleh validator $(\Sigma \mathrm{R})$ dengan jumlah skor ideal yang telah ditetapkan didalam angket validasi media pembelajaran (N) (Arifin 2010).

\section{HASIL DAN PEMBAHASAN}

\section{A. Hasil Penelitian}

Berdasarkan dari pengumpulan data, maka diperoleh hasil penelitian secara keseluruhan sesuai dengan prosedur pengembangan. Penyajian data secara keseluruhan tersebut akan dijelaskan secara terperinci melalui tabel di bawah ini :

Tabel 1. Data Hasil Penelitian Secara Keseluruhan

\begin{tabular}{|c|c|c|}
\hline No. & $\begin{array}{c}\text { Prosedur } \\
\text { Pengembangan }\end{array}$ & Temuan \\
\hline 1. & & Analisis Kebutuhan \\
\hline a. & $\begin{array}{l}\text { Proses } \\
\text { tematik }\end{array}$ & $\begin{array}{l}\text { - Pembelajaran tematik di SDN Pondokjoyo } 01 \text { sudah } \\
\text { berlangsung dengan menyenangkan. } \\
\text { - Peserta didik aktif dalam mengikuti proses } \\
\text { pembelajaran. } \\
\text { - Komunikasi antara guru dengan peserta didik } \\
\text { berlangsung dengan baik. }\end{array}$ \\
\hline b. & pembelajaran & - Penggunaan media pembelajaran di SDN Pondokjoyo \\
\hline
\end{tabular}


- Bentuk media pembelajaran yang digunakan di SDN Pondokjoyo 01 dalam bentuk satuan mata pelajaran.

- Media yang digunakan untuk Bahasa Indonesia berupa gambar-gambar seri dan tunggal, lingkungan dan bendabenda sekitar, dan papan sudut baca yang berisi beranekaragam bacaan untuk peserta didik.

- Media untuk Matematika berupa sempoa, beranekaragam bangun datar dan garis bilangan.
c. Kemampuan membaca dan menghitung peserta didik

- Peserta didik di SDN Pondokjoyo 01 sudah mengenal bilangan.

- Peserta didik di SDN Pondokjoyo 01 sudah mampu menjumlahkan satu bilangan.

- Peserta didik di SDN Pondokjoyo 01 sudah mampu membaca.

- Peserta didik kurang mampu didalam menyusun sebuah kalimat.

- Jumlah kosakata yang dimiliki oleh peserta didik masih kurang.

\begin{tabular}{|c|c|c|}
\hline d. & $\begin{array}{l}\text { Pengetahuan guru } \\
\text { mengenai penyediaan } \\
\text { media pembelajaran } \\
\text { Matematika dan Bahasa } \\
\text { Indonesia }\end{array}$ & $\begin{array}{l}\text { - Guru menyediakan media pembelajaran dengan } \\
\text { memanfaatkan benda-benda yang ada di sekitar. } \\
\text { - Guru memiliki pengetahuan yang cukup dalam } \\
\text { menyediakan media pembelajaran bagi peserta didik. } \\
\text { - Guru bukan berasal dari spesifikasi mata pelajaran. }\end{array}$ \\
\hline e. & $\begin{array}{l}\text { Kebutuhan Media } \\
\text { Pembelajaran Tematik }\end{array}$ & $\begin{array}{l}\text { - Sangat dibutuhkan media pembelajaran tematik di SDN } \\
\text { Pondokjoyo } 01\end{array}$ \\
\hline 2. & & Analisis Survei Permainan \\
\hline a. & Peneliti & $\begin{array}{l}\text { - Peserta didik sangat antusias dan bersemangat didalam } \\
\text { bermaian dengan media Cutter. } \\
\text { - Peserta didik saling berebut didalam menyusun kata } \\
\text { yang sesuai dengan gambar melalui media Cutter. } \\
\text { - Peserta didik ada yang pasif. }\end{array}$ \\
\hline b. & $\begin{array}{l}\text { Observasi Guru kelas } 1 \\
\text { SD }\end{array}$ & $\begin{array}{l}\text { - Media Cutter memudahkan peserta didik untuk belajar. } \\
\text { - Media Cutter unik dan mudah dibawa kemana saja oleh } \\
\text { peserta didik. } \\
\text { - Media Cutter aman bagi peserta didik. }\end{array}$ \\
\hline 3. & & Validasi Ahli \\
\hline a. & $\begin{array}{l}\text { Ahli Media } \\
\text { Pembelajaran }\end{array}$ & $\begin{array}{l}\text { - Media pembelajaran sudah bagus. } \\
\text { - Aturan permainan diperjelas. } \\
\text { - Gambar sepatu pada seri } 1 \text { (benda-benda dalam kelas) } \\
\text { diganti. }\end{array}$ \\
\hline b. & Ahli Materi & $\begin{array}{l}\text { - Media pembelajaran yang dikembangkan sudah sangat } \\
\text { bagus. }\end{array}$ \\
\hline c. & $\begin{array}{l}\text { Ahli Pembelajaran } \\
\text { (Guru kelas 1 SD) }\end{array}$ & $\begin{array}{l}\text { - Media pembelajaran yang dikembangkan sangat bagus } \\
\text { dan unik. } \\
\text { - Seri dalam media } \text { Cutter diperbanyak dengan tema yang } \\
\text { berbeda. }\end{array}$ \\
\hline 4. & & Uji Coba Lapangan \\
\hline a. & Uji coba skala kecil & $\begin{array}{l}\text { - Peserta didik kurang mengerti aturan permainan. } \\
\text { - Tulisan aturan permainan terlalu kecil. }\end{array}$ \\
\hline
\end{tabular}


PTK, Vol.2 No.1 2021

ISSN: 2747-1977 (Print) / 2747-1969 (Online)

DOI: https://doi.org/10.53624/ptk.v2i1.54

- Peserta didik antusias dalam bermain dengan media Cutter.

- Peserta didik dapat menyusun kata yang sesuai dengan gambar.

- Peserta didik mampu menjumlahkan setiap skor yang ada pada media Cutter setelah tersusun menjadi sebuah kata.

b. Uji coba skala besar

- Peserta didik sangat antusias dalam menggunakan media Cutter.

- Peserta didik bekerjasama secara kelompok dalam menyusun sebuah kata yang sesuai dengan gambar.

- Peserta didik mampu menjumlahkan setiap skor yang ada pada media Cutter setelah tersusun menjadi sebuah kata.

\section{Analisis Kebutuhan}

Berdasarkan hasil angket analisis kebutuhan diperoleh data bahwa penggunaan media pembelajaran sudah bervariasi tetapi bentuknya masih dalam satuan mata pelajaran. Proses pembelajaran tematik di kelas belum menggunakan media pembelajaran tematik karena sekolah tidak memiliki media pembelajaran tematik. Sehingga berdasarkan hasil analis kebutuhan sangat dibutuhkan atau sangat perlu sebuah media pembelajaran tematik didalam proses pembelajaran untuk meningkatkan kemampuan anak secara utuh.

\section{Analisis Survei Permainan}

Berdasarkan hail observasi diperoleh data bahwa semua kriteria didalam penggunaan media pembelajaran Cutter telah mendapatkan nilai yang baik dari para observer. Hal ini berarti peserta didik sudah mampu menggunakan media pembelajaran tematik yang dikembangkan dengan baik pula. Meskipun ada beberapa peserta didik yang masih pasif pada saat penggunaan media Cutter. Hal ini disebabkan karena peserta didik tersebut tidak mendapatkan media Cutter.

\section{Validasi Ahli}

Berdasarkan aspek penilaian yang dilakukan oleh ahli media, maka dapat diketahui bahwa media pembelajaran yang dikembangkan memperoleh persentase sebesar $92 \%$, dari ahli materi memperoleh persentase sebesar 94\%, dan dari ahli pembelajaran yaitu guru kelas 1 di SDN Pondokjoyo 01 memperoleh persentase sebesar 100\%. Apabila dikonversikan dengan skala Likert hasil skor dari ahli media di atas menyatakan bahwa kelayakan media pembelajaran tematik Cutter ini terletak pada kategori kualifikasi sangat baik dengan keterangan sangat layak digunakan sebagai media pembelajaran tematik tanpa revisi.

4. Uji Coba Lapangan

a. Uji coba skala kecil

Uji coba skala kecil berjumlah 10 peserta didik dari jumlah total peserta didik kelas 1 di SDN Pondokjoyo 01 sebanyak 63 yang terdiri dari 32 peserta didik kelas 1A dan 31 peserta 
didik kelas 1B. Jumlah skor respon positif yang didapat dari angket respon peserta didik adalah 338 sehingga persentase data hasil angket respon positif peserta didik berjumlah 97\%. Jika dikonversikan ke dalam skala Likert, maka media pembelajaran tematik Cutter dinyatakan mendapat respon positif dari peserta didik dan sangat valid.

b. Uji coba skala besar

Uji coba skala besar ini dilakukan kepada seluruh peserta didik kelas I SDN Pondokjoyo 01 yakni sejumlah 53 peserta didik setelah dikurangi jumlah dari responden uji coba skala kecil. Berdasarkan hasil data yang diperoleh dari penelitian pelaksanaan uji coba dalam skala besar ini, peneliti mendapatkan hasil yang memuaskan dari kedua observer dan sudah tidak ada kekurangan pada media tematik Cutter.

\section{B. Pembahasan Hasil Penelitian}

\section{Analisis Kebutuhan}

Berdasarkan hasil angket, diketahui bahwa pada kelas I di SDN Pondokjoyo 01 dan di SDN Sidomulyo 03 belum menggunakan media pembelajaran tematik, tetapi hanya menggunakan media pembelajaran sebatas media pembelajaran dalam bentuk satuan mata pelajaran. Analisis kemampuan membaca dan menghitung peserta didik yang dilakukan diperoleh data bahwa peserta didik telah lancar dalam menjumlahkan satu bilangan dan juga telah lancar dalam membaca tetapi belum begitu lancar dalam menyusun kalimat. Hal ini disebabkan karena jumlah kosakata yang dimiliki oleh peserta didik di kelas 1 SD masih sedikit. Sehingga media pembelajaran tematik Cutter ini sangat cocok digunakan bagi peserta didik sekolah dasar sebagai alat untuk meningkatkan jumlah kosakata yang dimiliki.

\section{Analisis Survei Permainan}

Penggunaan media pembelajaran tematik Cutter ini digunakan dalam sebuah permainan “Ayo Susunlah Aku..!”. berdasarkan hasil observasi yang dilakukan oleh peneliti dan beberapa observer diperoleh data bahwa peserta didik sangat antusias dan bersemangat sekali didalam bermain dengan menggunakan media Cutter dan saling berlomba untuk menyusun kata yang sesuai gambar berdasarkan seri Cutter yang dimiliki.

\section{Validasi Ahli}

Hasil penilaian dari validasi ahli media pembelajaran menunjukkan persentase 92\%, ahli materi yang menunjukkan persentase 94\%, dan guru kelas 1 SDN Pondokjoyo 01 yang menunjukkan persentase $100 \%$. Persentase validasi media pembelajaran dari ahli media pembelajaran, ahli materi, dan guru kelas 1 SD di SDN Pondokjoyo 01 lebih dari $61 \%$ maka media pembelajaran tematik yang dikembangkan merupakan media pembelajaran yang sangat layak digunakan sebagai media pembelajaran terutama sebagai media pembelajaran tematik (Bahasa Indonesia dan Matematika) (Arikunto, 2010). 
PTK, Vol.2 No.1 2021

ISSN: 2747-1977 (Print) / 2747-1969 (Online)

DOI: https://doi.org/10.53624/ptk.v2i1.54

\section{Uji Coba Lapangan}

Tahapan uji coba skala kecil yang telah dilaksanakan menunjukkan persentase $97 \%$ dengan kategori sangat baik. Sedangkan penilaian dari uji coba skala besar yaitu menunjukkan persentase $99 \%$ dengan kategori sangat baik. Jika persentase tersebut dikonversikan ke dalam skala Likert, maka media pembelajaran tematik Cutter dinyatakan mendapat respon positif dari peserta didik. Hal ini berarti angka persentase tersebut membuktikan, bahwa media pembelajaran tematik yang dikembangkan dapat digunakan sebagai media pembelajaran tematik Matematika dan Bahasa Indonesia dengan tema lingkungan.

\section{KESIMPULAN}

Berdasarkan penelitian dan pengembangan media pembelajaran yang dilakukan di SDN Pondokjoyo 01 diperoleh hasil sebuah produk media pembelajaran tematik Cutter (Cube Letter) yang merupakan sebuah media baru dari penggabungan media kotak huruf dan puzzle. Media ini digunakan didalam permainan bahasa Indonesia dan matematika yang dapat meningkatkan kemampuan kognitif, afektif, psikomotor, sosio-emosional, kemampuan keagamaan (melatih kesabaran) dan kemampuan kinestetik peserta didik. Dari hasil uji kelayakan yang dilakukan oleh ahli media, ahli materi dan ahli pembelajaran, serta dari hasil uji coba lapangan skala kecil dan skala besar diperoleh hasil bahwa media pembelajaran tematik Cutter ini memiliki kualifikasi sangat baik dengan keterangan sangat layak digunakan sebagai media pembelajaran. Hasil penelitian ini diharapkan dapat memotivasi guru untuk memvariasikan media pembelajaran yang ada di kelas sehingga peserta didik menjadi kreatif dan bisa mendapatkan pembelajaran yang lebih bermakna..

\section{DAFTAR PUSTAKA}

Akbar, Sa'dun. 2010. Penelitian Tindakan Kelas, Filosofi, Metodologi. Yogyakarta: CV Citra Implementasi Media

Arifin. 2010. Penelitian Pendidikan Pendekatan Kuantitatif dan Kualitatif. Yogyakarta: Lilin Persada press.

Arikunto, Suharsimi. 2010. Prosedur Suatu Pendekatan Praktik. Jakarta: Rineka Cipta.

Hesty. 2008. Implementasi Model Pembelajaran Tematik Untuk Meningkatkan Kemampuan

Dasar Siswa Sekolah Dasar." Lembaga Penjaminan Mutu Pendidikan. Propinsi Kepulauan Bangka Belitung Pangkalpinang.

Resmini, Novi. 2008. Simulasi Kreatif dalam Permainan Bahasa Indonesia. Jurnal Kependidikan, (Online), (http://www.um.ac.id), diakses 3 Maret 2008.

Sadiman, Arief S, dkk. 2010. Media Pendidikan: Pengertian Pengembangan dan Pemanfaatannya. Jakarta : Rajawali Pers.

Sukmadinata. 2007. Metode Penelitian Pendidikan. Bandung: Remaja Rosdakarya. 
PTK, Vol.2 No.1 2021

ISSN: 2747-1977 (Print) / 2747-1969 (Online)

DOI: https://doi.org/10.53624/ptk.v2i1.54

Trianto. 2011. Desain Pengembangan Pembelajaran Tematik Bagi anak usia dini TK \& anak usia kelas awal SD/MI. Jakarta: Kencana Perdana Media Group.

Yus, Anita. 2011. Penilaian Perkembangan Belajar Anak Taman Kanak-kanak. Jakarta: Kencana Perdana Media Group. 